Journal of Reproduction and Development, Vol. 40, No. 4, 1994

-Research Note-

\title{
Effect of $\beta$-Merchaptoethanol on the Preimplantation Development of Bovine Embryos Fertilized In Vitro
}

\author{
Seizo HAMANO, Masashige KUWAYAMA, Masashi TAKAHASHI'), \\ Naomichi OKAMURA ${ }^{2)}$, Akira OKANO ${ }^{1)}$ and Takashi NAGAI ${ }^{3)}$ \\ Animal Bio-Technology Center, Livestock Improvement Association of Japan, Inc., \\ 3-21-10 Higashishinagawa, Shinagawa-ku, Tokyo 140, \\ ${ }^{1)}$ Department of Animal Reproduction, National Institute of \\ Animal Industry, Tsukuba Norindanchi, Ibaraki 305, \\ ${ }^{2)}$ Division of Biochemistry, Tsukuba University, \\ School of Medicine, Ibaraki 305, and \\ ${ }^{3)}$ Department of Animal Production, Tohoku National Agricultural \\ Experiment Station, Morioka 020-01, Iwate, Japan
}

\begin{abstract}
The present study investigated effects of $\beta$-merchaptoethanol $(\beta-\mathrm{ME})$ on the development of bovine embryos derived from in-vitro matured and fertilized (IVM-IVF) oocytes. IVM oocytes were inseminated with frozen-thawed bovine sperm, and at 24,48 and $72 \mathrm{~h}$ after insemination, 2-, 8- and 16-cell embryos, respectively, were transferred to TCM-199 medium containing $5 \%$ fetal bovine serum and $0,5,10,20,50$ or $100 \mu \mathrm{m} \beta$-ME without a cumulus cell monolayer or with a cumulus cell monolayer but without addition of $\beta$-ME as a control. All embryos were subsequently incubated such that the total duration of culture was 8 days. The addition of low concentrations ( 5 or $10 \mu \mathrm{M})$ of $\beta$-ME significantly enhanced the development of all the embryos to the blastocyst stage. High concentrations (20,50 or $100 \mu \mathrm{M})$ of $\beta$-ME were effective only for the development of 8and 16-cell embryos, but not of 2-cell embryos, to the blastocyst stage. Compared with embryos in the co-culture system (control), 2-cell embryos that were cultured with $\beta$-ME but without a cumulus cell monolayer showed significantly lower rates of development to the blastocyst stage. However, even though without a cumulus cell monolayer, 8-cell embryos showed the same rates of development to the blastocyst stage as controls when low concentrations of $\beta$-ME ( 5 or $10 \mu \mathrm{M}$ ) were added to the medium. Furthermore, significantly higher rates of development of embryos to the blastocyst stage were obtained when 16-cell embryos were cultured in medium supplemented with 20 $\mu \mathrm{M} \beta$-ME than that of controls. Twenty blastocysts developed from 16 cell IVM-IVF embryos in the medium containing $20 \mu \mathrm{M} \beta$-ME were transferred to 20 recipients, and 11 of them became pregnant, resulting in 10 calves. These results indicate that $\beta$-ME is effective for blastocyst development of embryos that are cultured without a cumulus cell monolayer, and the effect is remarkable for embryos of advanced stages.
\end{abstract}

Key words: In-vitro fertilization, Bovine embryo, In-vitro culture, $\beta$-Merchaptoethanol.

(J. Reprod. Dev. 40: 355-359, 1994)

$t$ is well established that live calves can be obtained by in vitro maturation and fertilization of

Accepted for Publication: July 8, 1994

Crrespondence: S. Hamano follicular oocytes collected from the ovaries of slaughtered cows [1-3]. Successful in-vitro maturation and fertilization (IVM-IVF) of bovine embryos was achieved in co-culture systems with 
fibroblast monolayers [4], trophoblastic vesicles [5], oviductal cell monolayers [6] or cumulus cell monolayers [7, 8]. However, these co-culture systems are time consuming, labor intensive, and the results are quite variable. Furthermore, analysis of the cellular physiology of embryos requires a reliable, simple embryo culture system that eliminates the potential interference of co-cultured cells. Recently, Takahashi et al. [9] reported that $\beta$-merchaptoethanol $(\beta$-ME) enhances development of IVM-IVF bovine oocytes from the 6- to 8-cell stages to blastocysts without co-culture. However, the effect of $\beta$-ME on the development of embryos at earlier stages has not been investigated. The present study evaluates the effects of $\beta$-ME on development of bovine IVM-IVF embryos from different developmental stages to the blastocyst stage without a cumulus cell monolayer.

\section{Materials and Methods}

\section{Oocyte collection and in vitro maturation}

Ovaries of Japanese Black cows were obtained from a slaughter house and transported to the laboratory within $1 \mathrm{~h}$ of slaughter in $0.9 \%$ saline containing $0.1 \mathrm{mg} / \mathrm{ml}$ Kanamycin at $37 \mathrm{C}$. All visible follicles ( 2 to $5 \mathrm{~mm}$ in diameter) on the ovarian surface were aspirated by syringe with an 18-gauge needle.

Cumulus-oocyte complexes were washed several times with maturation medium and cultured in a $\mathrm{CO}_{2}$ incubator $\left(2 \% \mathrm{CO}_{2}\right.$ in air at $\left.38.5 \mathrm{C}\right)$ for 20 to $21 \mathrm{~h}$ in $1.0 \mathrm{ml}$ of maturation medium under mineral oil (Squibb, Wako Pure Chemical, Osaka, Japan) in a culture dish $(35 \times 10 \mathrm{~mm}$, Nunclon 153066 , Inter-med., Roskilde, Denmark). The maturation medium was TCM-199 (Earle's salts with $25 \mathrm{mM}$ HEPES, GIBCO, Grand Island, NY, USA) supplemented with 5\% heat treated fetal bovine serum (FBS, Filtron, PTY, Ltd., Victoria, Australia) and antibiotics.

\section{Sperm capacitation}

Sperm capacitation was induced by the method described by Parrish et al. [10]. Frozen semen from a Japanese Black bull in a $0.5 \mathrm{ml}$ straw was thawed at $37 \mathrm{C}$. Semen was suspended in $10 \mathrm{ml}$ of BO medium[11] containing $10 \mathrm{mM}$ caffeine (Sigma Chemical, St. Louis, MO, USA), and sperm were washed twice by centrifugation for $5 \mathrm{~min}$ at $800 \times$ g. After washing, the sperm concentration was adjusted to $2 \times 10^{7}$ cells $/ \mathrm{ml}$. Then the sperm suspension was diluted 2-fold with BO medium containing $10 \mathrm{mg} / \mathrm{ml}$ bovine serum albumin (Fraction V, Wako Pure Chemical, Japan) and $10 \mu \mathrm{g} / \mathrm{ml}$ heparin (NOVO-Heparin, Kodama Industries, Tokyo, Japan).

\section{In vitro fertilization}

At the end of maturation culture, cumulus-oocytes complexes were washed twice by pipetting 2 or 3 times in $\mathrm{BO}$ medium and then introduced into $0.5 \mathrm{ml}$ drops of sperm suspension. Oocytes and spermatozoa were co-cultured for $5 \mathrm{~h}$. The maturation medium that contained cumulus cells from which the oocytes had been removed was kept in a $\mathrm{CO}_{2}$ incubator. All inseminated oocytes, still surrounded by cumulus cells with attached motile spermatozoa, were then introduced into this maturation medium with cumulus cells.

\section{In vitro coculture of fertilized oocytes}

At 24,48 or $72 \mathrm{~h}$ after insemination, oocytes were removed from cumulus cell masses by pipetting and examined for their stages of cleavage. The 2-, 8- and 16-cell embryos, respectively, were further cultured in $1.0 \mathrm{ml}$ of TCM-99 with 5\% FBS and antibiotics under mineral oil. For embryos cultured without a cumulus cell monolayer, $0,5,10$, 20,50 or $100 \mu \mathrm{M} \beta$-ME was added to the medium. Controls were cultured with a cumulus cell monolayer and no $\beta$-ME. Six to 8 days after insemination, embryo development to the blastocyst stage was examined under a microscope.

\section{Embryo transfer}

Twenty blastocysts obtained by in vitro culture of 16-cell IVM-IVF embryos in medium containing $20 \mu \mathrm{M} \beta$-ME without a cumulus cell monolayer were transferred to 20 recipients.

\section{Statistical analysis}

Statistical significance of the results was evaluated by Student's $t$-test and Chi-square test.

\section{Results}

As shown in Table 1, when low concentrations (5 or $10 \mu \mathrm{M}$ ) of $\beta$-ME were added to culture medium without cumulus cells, significantly higher rates 
of development to the blastocyst stage were observed than when embryos were cultured without $\beta$-ME irrespective of the initial developmental stage. High concentrations $(20,50$ or $100 \mu \mathrm{M})$ of $\beta$ ME were effective for blastocyst development from 8- and 16-cell embryos but not from 2-cell embryos. Two-cell embryos that were cultured in medium containing $\beta$-ME without cumulus cells showed a significantly lower rate of the development to the blastocyst stage than controls. However, 8-cell embryos showed the same rates of the development to the blastocyst stage as controls when low concentrations ( 5 or $10 \mu \mathrm{M}$ ) of $\beta$-ME were added to the medium. Furthermore, significantly higher rates of development to the blastocyst stage were obtained when 16-cell embryos were cultured in the medium containing $20 \mu \mathrm{M} \beta$-ME than when embryos were co-cultured with a cumulus cell monolayer without addition of $\beta$-ME (control).

Twenty blastocysts were developed from 16-cell embryos in medium containing $20 \mu \mathrm{M} \beta$-ME without a cumulus cell monolayer. After transfer into
20 recipients, 11 of these became pregnant and 10 calves were born.

\section{Discussion}

Recently, Takahashi et al. [9] reported that including $\beta-\mathrm{ME}$ and cysteamine in culture media facilitates development of bovine 6- to 8-cell embryos from IVM-IVF to the blastocyst stage without any feeder cells. Our results indicate that $\beta$-ME is also effective for development of bovine 2- and 16cell embryos, and the effect is remarkable for embryos of advanced stages.

Even without a co-cultured cumulus cell monolayer, 16-cell embryos cultured in medium containing $\beta$-ME (5 to $100 \mu \mathrm{M}$; all concentrations used in the present study) showed blastocyst development at rates comparable to co-cultured embryos. A significantly higher rate of development to the blastocyst stage was obtained when they were cultured with $20 \mu \mathrm{M} \beta$-ME than when co-cultured with a cumulus cell monolayer. How-

Table 1. Effect of various concentrations of $\beta$-merchaptoethanol $(\beta$-ME) on development of bovine 2-, 8- and 16-cell ${ }^{1)}$ embryos obtained by in-vitro maturation and fertilization of oocytes

\begin{tabular}{|c|c|c|c|c|c|c|c|}
\hline \multirow{2}{*}{$\begin{array}{l}\text { Source } \\
\text { of } \\
\text { embryos }\end{array}$} & \multirow{2}{*}{$\begin{array}{l}\text { Concentrations } \\
\text { of } \\
\beta \text {-ME }(\mu \mathrm{M})\end{array}$} & \multirow{2}{*}{$\begin{array}{l}\text { No. of } \\
\text { traials }\end{array}$} & \multirow{2}{*}{$\begin{array}{c}\text { No. of } \\
\text { embryos } \\
\text { cultured }\end{array}$} & \multicolumn{3}{|c|}{$\begin{array}{l}\text { No. of embryos developed } \\
\text { to blastocysts on }\end{array}$} & \multirow{2}{*}{$\begin{array}{l}\text { Total No. } \\
\text { of } \\
\text { blastocysts }\end{array}$} \\
\hline & & & & Day 62) & Day 72) & Day 8²) & \\
\hline \multirow[t]{7}{*}{ 2-cell } & 0 & 5 & 100 & 2 & 3 & 0 & $5^{a}$ \\
\hline & 5 & 5 & 100 & 7 & 12 & 2 & $21^{b}$ \\
\hline & 10 & 5 & 100 & 5 & 13 & 1 & $19^{b}$ \\
\hline & 20 & 5 & 100 & 2 & 5 & 2 & $9 a$ \\
\hline & 50 & 5 & 100 & 2 & 8 & 0 & $10^{a}$ \\
\hline & 100 & 5 & 100 & 2 & 5 & 0 & 7 \\
\hline & control $^{3)}$ & 5 & 100 & 14 & 20 & 5 & $39 c$ \\
\hline \multirow[t]{7}{*}{ 8-cell } & 0 & 5 & 100 & 1 & 3 & 0 & $4^{\mathrm{a}}$ \\
\hline & 5 & 5 & 100 & 8 & 24 & 7 & $39 \mathrm{~b}$ \\
\hline & 10 & 5 & 100 & 20 & 27 & 3 & $50^{\mathrm{b}}$ \\
\hline & 20 & 5 & 100 & 6 & 15 & 4 & $25^{c}$ \\
\hline & 50 & 5 & 100 & 6 & 9 & 2 & $17^{\mathrm{cd}}$ \\
\hline & 100 & 5 & 100 & 2 & 7 & 4 & $13^{\mathrm{d}}$ \\
\hline & control $^{3)}$ & 5 & 100 & 13 & 24 & 15 & $52^{b}$ \\
\hline \multirow[t]{7}{*}{ 16-cell } & 0 & 5 & 100 & 8 & 15 & 0 & $23^{a}$ \\
\hline & 5 & 5 & 100 & 27 & 19 & 14 & $60^{\mathrm{b}}$ \\
\hline & 10 & 5 & 100 & 28 & 20 & 11 & $59 \mathrm{~b}$ \\
\hline & 20 & 5 & 100 & 37 & 30 & 7 & $74^{\mathrm{c}}$ \\
\hline & 50 & 5 & 100 & 34 & 25 & 13 & $72^{b c}$ \\
\hline & 100 & 5 & 100 & 29 & 20 & 7 & $56^{b}$ \\
\hline & control $^{3)}$ & 5 & 100 & 24 & 30 & 9 & $63^{b}$ \\
\hline
\end{tabular}

1)Two, 8- and 16-cell embryos were collected 24, 48 and $72 \mathrm{~h}$, respectively, after insemination. 2)Day $0=$ Day of insemination. 3)Embryos were cultured with a cumulus cell monolayer without $\beta$-ME. Different superscripts within columuns for the same source of embryos denote significant differences. 
ever, the beneficial effect of $\beta$-ME on the development of embryos was not so evident for 2-cell embryos, and the addition of $\beta$-ME at high concentrations (20 to $100 \mu \mathrm{M}$ ) had no effect on their development. Although the addition of $\beta$-ME to the culture medium significantly enhanced the development of 8-cell embryos, only low (5 and 10 $\mu \mathrm{M})$ concentrations of $\beta$-ME were found to be effective for their development to the blastocyst stage when compared with those of co-cultured embryos.

Therefore, it was found that high concentrations (20 to $100 \mu \mathrm{M}$ ) of $\beta$-ME are not effective for development of 2- and 8-cell embryos to the blastocyst stage but are effective for 16-cell embryos. In contrast, Takahashi et al. [9] reported that the percentage of 6- to 8-cell embryos developing to the blastocyst stage was significantly higher when embryos were cultured in medium supplemented with a high concentration of $\beta-\mathrm{ME}(50 \mu \mathrm{M})$ than when they were cultured in the medium supplemented with a low concentration of $\beta$-ME $(10 \mu \mathrm{M})$. The reason for this discrepancy with respect to effective concentrations of $\beta$-ME on the development of embryos to the blastocyst stage is not clear. Differences in the source of oocytes (Japanese black vs Holstein) and/or culture conditions $\left(2 \% \mathrm{CO}_{2}\right.$ in air vs $5 \% \mathrm{CO}_{2}$ in air) might be reasons for this difference. Because 10 calves were born after the transfer of blastocysts obtained by in vitro culture with $\beta$-ME to recipients, addition of $\beta$-ME was determined not to be toxic to the embryos.

At present, the mechanism by which different concentrations of $\beta$-ME enhance development of embryos at different stages (2-, 8- and 16-cell) to the blastocyst stage is not entirely understood. However, it is of interest that bovine IVM-IVF embryos at 2- and 4-cell stages can metabolize glutamine at a high rate, and then the rate declines before rising at a later preimplantation stage [12]. It has been postulated that the beneficial effects of glutamine on the development of embryos may arise from its ability to counteract lipid peroxidation under circumstances when other substrates are relatively ineffective [12]. If the promoting effect of $\beta$-ME on the development of IVM-IVF embryos is to increase intracellular concentration of glutathione, known to scavenge free radicals in the cells [9], embryos at 4- and 8-cell stages may not need a high concentration of $\beta$-ME in the culture medium to increase intracellular glutathione levels because the embryos may utilize glutamine to scavenge free radicals. Higher concentrations of glutathione in the cells and/or $\beta-\mathrm{ME}$ in the medium than needed might be detrimental for development of embryos.

Further investigations are required to explain the relationships between the optimal concentration of $\beta$-ME for development of embryos and their intracellular glutathione levels. Nevertheless, the usefulness of such a thiol compound in creating improved conditions for in vitro culture of IVMIVF embryos at early stages without co-culture is quite evident.

\section{Acknowledgment}

We thank Ms. Akiko Koikeda for her technical assistance.

\section{References}

1. Hanada A, Suzuki T, Shioya Y. Birth of calves from nonsurgical transfer of blastocysts originated from in vitro fertilized oocytes matured in vitro. Proc 78th Ann Meet Jpn Soci Zootech Sci 1986; p18 (Abstr).

2. Sirard MA, Lambert RD. Birth of calves after in vitro fertilization using laparoscopy and rabbit oviduct incubation of zygotes. Vet Res 1986; 119: 167169.

3. Lu KH, Gordon I, Chen HB, Gallagjer HB, McGovern H. Birth of twins after transfer of cattle embryos produced in vitro technique. Vet Res 1988; 122: 539-540.
4. Kuzan FB, Wright RW Jr. Observations on the development of bovine morula on various cellular and non-cellular substrata. J Anim Sci 1982; 54: 811-816.

5. Heyman $Y$, Menezo $Y$, Chesne P, Camus S, Garnier V. In vitro cleavage of bovine and ovine early embryos: improved development using coculture with trophoblastic vesicles. Theriogenology 1987; 25: 59-68.

6. Aoyagi Y, Fukui Y, Iwazumi Y, Urakawa M, Ono H. Effects of culture systems on development of in vitro fertilized bovine ova into blastocysts. Theriogenology 1990; 34: 749-759. 
7. Goto K, Kajihara Y, Kosaka S, Koba M, Nakanishi Y, Ogawa K. Pregnancies after co-culture of cumulus cells with bovine embryos derived from invitro fertilization of in-vitro matured follicular oocytes. J Reprod Fert 1988; 83: 753-758.

8. Fukuda $Y$, Ichikawa $M$, Naito K, Toyoda $Y$. Birth of normal calves resulting from bovine oocytes matured, fertilized, and cultured with cumulus cells in vitro up to the blastocyst stage. Biol Reprod 1990; 42: 114-119.

9. Takahashi M, Nagai T, Hamano S, Kuwayama M, Okamura N, Okano A. Effect of thiol compounds on in vitro development and intracellular gulutathione content of bovine embryos. Biol Reprod 1993; 49: 228-232.

10. Parrish JJ, Susko-Parrish JL, Leibfried-Rutledge ML, Critser E, Eyestone WH, First NL. Bovine in vitro fertilization with frozen thawed semen. Theriogenology 1986; 25:591-600.

11. Brackett BG, Oliphant G. Capacitation of rabbit spermatozoa in vitro. Biol Reprod 1975; 12: 260274.

12. Rieger D. Relationships between energy metabolism and development of early mammalian embryos. Theriogenology 1992; 37: 75-93. 